\title{
Contribution of social media to cetacean research in Southeast Asia: illuminating populations vulnerable to litter
}

\section{Amber Coram ${ }^{1}$ (D) . Neil Angelo S. Abreo ${ }^{2}$ D $\cdot$ Robert P. Ellis $^{1}$ (D) $\cdot$ Kirsten F. Thompson $^{1}$ (iD}

Received: 22 December 2020 / Revised: 23 April 2021 / Accepted: 29 April 2021 /

Published online: 18 May 2021

(C) The Author(s) 2021

\begin{abstract}
Litter in the marine environment, in particular plastic, is a significant threat to marine megafauna. Cetaceans are known to ingest or become entangled in marine debris, likely impacting individuals and populations. Southeast Asia is a biodiversity hotspot and harbours a diverse cetacean assemblage. However, there are key knowledge gaps relating to the impact of litter in this region due the lack of experts to survey its vast coastlines. This study aims to address such gaps by using social media, gathering data from Facebook posts relating to cetacean strandings and litter across Southeast Asia between 2009 and 2019. Results show that at least 15 cetacean species have been negatively affected by litter, with ingestion most commonly affecting deep-diving species. Epipelagic and mesopelagic foragers were most vulnerable to entanglement. Davao in the Philippines was identified as a litter-related stranding hotspot. The Irrawaddy dolphin (Orcaella brevirostris) and pygmy sperm whale (Kogia breviceps) are particularly vulnerable to litter. The combination of social media and peer reviewed literature can help build a more complete picture of the spatial distribution of marine litter and the scale of the impact it has on cetacean populations. In this study we provide details of a valuable online tool for helping to understand the impact of marine litter on cetaceans and other charismatic species that are a focus of community engagement.
\end{abstract}

Keywords Cetacean $\cdot$ Social media $\cdot$ Plastic pollution $\cdot$ Southeast Asia $\cdot$ Facebook

Communicated by Anurag chaurasia.

This article belongs to the Topical Collection: Coastal and marine biodiversity.

Kirsten F. Thompson

k.f.thompson@exeter.ac.uk

1 College of Life and Environmental Sciences, University of Exeter, Exeter, UK

2 Graduate Studies, Institute of Aquatic and Applied Sciences, Davao Del Norte State College, Davao del Norte, Philippines 


\section{Introduction}

\section{Marine debris in Southeast Asia}

Marine debris is defined as any persistent manufactured or processed solid material discarded, disposed of or abandoned in the marine and coastal environment (Galgani et al. 2010). Plastics are typically the main component, accounting for approximately 60 to $80 \%$ by volume (Moore 2008), most of it derived from mismanaged waste from land (Jambeck et al. 2015). Plastic contamination of the marine environment was first reported in the 1960s and has significantly increased over recent decades (Ryan 2015). Due to its persistence and buoyancy, marine plastic can disperse great distances, and as a result has been detected worldwide in all major marine habitats (Moore 2008). Its ubiquitous presence is of increasing concern due to the negative consequences it has on marine ecosystems (STAP 2011). Although marine plastic has been commonly observed across all oceans (Ryan 2015), there is a vast amount of spatial variability. Southeast Asia is the third most populous geographical region globally with $70 \%$ of its human population living in coastal areas (Bryant et al. 1998). Coastal settlements, along with massive industrial development, contribute towards the large volumes of plastic released into the marine environment, often transported there by rivers, drainage systems or wind (Todd et al 2010). Six countries in this region are listed in the top 20 that mismanage their waste worldwide, with on average $79 \%$ of waste, primarily plastic, ending up in the ocean (Jambeck et al. 2015). Southeast Asia is a global centre of marine biodiversity, with many species suffering significant declines in recent years (Yamakita et al. 2017). However, marine plastic research in the ASEAN region (defined as Indonesia, Vietnam, Thailand, Singapore, Malaysia, Philippines, Cambodia, Laos PDR, Myanmar, and Brunei Darussalam (asean.org)) is still in its infancy. Five out of the ten ASEAN member states have no published studies on the ecological and environmental impacts of marine plastics (Lyons et al. 2019). Data on the sources and quantity of plastic waste are lacking, highlighting a need for urgent risk assessment and the identification of hotspots of plastic pollution to help mitigate release into the ocean (Lasut et al. 2018).

\section{Marine debris and cetaceans in Southeast Asia}

Marine megafauna (defined as marine mammals, seabirds, marine and estuarine reptiles, and large fish such as billfishes, sharks and tuna) are particularly vulnerable to plastic pollution (Provencher et al. 2017; Tavares et al. 2019). According to Gall and Thompson (2015) entanglement and ingestion of plastic are the most frequent ways in which megafauna interact with debris and the frequency of reported encounters is increasing. $17 \%$ of species reported to interact with plastic are classified as near threatened, vulnerable, endangered or critically endangered on the IUCN Red List. Crucially, marine plastic could be contributing to population declines. $78.9 \%$ of marine mammal species are reported to have ingested or become entangled in plastic; this includes cetaceans, many of which are already under threat from multiple anthropogenic activities (Poeta et al. 2017).

Plastic can impact cetacean populations in a diversity of lethal and sub-lethal ways. Entanglement can cause drowning, lacerations, amputations, infections and altered behaviour such as decreased ability to avoid predators and obtain food, prolonged illness and death (Laist 1987, 1997). Marine debris has been found in sperm whales since the early 
twentieth century, when fishing hooks were found in stranded individuals in Shetland, Scotland (Turner 1904). de Stephanis et al. (2013) reported a stranded sperm whale in Granada, Spain, which had a large mass of compacted plastics in its stomach. Between January and February 2016, 30 sperm whales also stranded along the coast of the North Sea. Nine of these whales had marine debris in their gastro-intestinal tract, with up to $25 \mathrm{~kg}$ of debris collected from a single individual (Unger et al. 2016). A study of North Atlantic right whales by van der Hoop et al. (2016), demonstrated how entanglement in fishing gear increases the energy requirements of an entangled whale by up to $102 \%$. This substantial energetic cost has detrimental effects, possibly causing severe emaciation and mortality. Abreo et al. (2016) reported the necropsy of a rare Deraniyagala's beaked whale (Mesoplodon hotaula) which had ingested a $133 \mathrm{~cm}$ polypropylene rope, leading to fatal blockage of the gastrointestinal tract. Plastic can remain in an animal's stomach for long periods of time, and can consequently cause satiation, ulcerations and lacerations, resulting in infections, internal bleeding and consequently prolonged illness and suffering (Day et al. 1985). Plastics can also be a potential source for toxic chemicals when ingested (Ryan 1987).

Southeast Asia is a hotspot for cetaceans, but species distributions, threats and population status are not well characterised due to a lack of funding and infrastructure in many countries (SEAMAM III 2015). Southeast Asia also has an extensive and difficult to survey coastline extending over 100,000 km and Indonesia and the Philippines alone consist of 24,000 islands (Bryant et al. 1998).

In addition to a high diversity of marine megafauna in Southeast Asia, there are also several freshwater and estuarine species. For example, both Indo-Pacific humpback dolphin (Sousa chinensis) (Vulnerable) and Irrawaddy dolphins (Orcaella brevirostris) (Endangered) inhabit freshwater and estuarine ecosystems and face numerous threats that are implicated in their decline (Minton et al. 2017; Jefferson et al. 2017). These estuarine species often exist in fragmented and isolated populations with river pollution (both chemical and litter) causing significant conservation concern (Kreb et al. 2010). There is, therefore, an urgent need for more conservation-based research into the ecology, distribution and threats of plastic pollution on Southeast Asian cetaceans, encompassing estuarine, coastal and offshore species, to assess impacts at both the individual- and population- level (Abreo et al. 2019).

\section{Published literature}

There is a lack of literature relating to cetaceans and litter, especially considering Southeast Asia's large contribution of marine plastic pollution (Jambeck et al. 2015). According to the Web of Science, of the ASEAN member states, the Philippines was the subject of the most English language studies published between 2009 and $2019(n=4)$, followed by Thailand $(n=2)$. Singapore, Cambodia and Indonesia all had one relevant study; and the remaining member states none.

These studies include Obusan et al. (2016) who analysed strandings from 1998 to 2013 in the Philippines, with notes on the impact of fisheries interactions, and vulnerable cetacean species. The study reports that $33 \%$ of the strandings were confirmed to be related to human interaction. Aragones et al. (2010) discussed the causes of cetacean strandings in the Philippines but did not specifically focus on marine debris. Other studies focus on individual species; for example, Baird and Beasley (2005) revealed how bycatch is a threat to the Irrawaddy dolphin (Orcaella brevirostris) population in the Mekong River. Overall however, there are no standardised methods for assessing the extent of the marine litter 
problem (Nelms et al. 2015), and therefore, no comparison could be made from literature between each ASEAN member state.

\section{Social media data collection}

To address a lack of data, both on plastics and cetaceans in Southeast Asia, we used data from social media posts. Social media is an efficient tool for this purpose due to its accessibility and global reach (Bik and Goldstein 2013), Facebook being the most widely used social media platform with 2.6 billion users at the start of 2020 (www.statista.com). Previous studies show the utility of social media for such research. For example, Sidlauskas et al. (2011) highlighted the utility of such platforms for successfully identifying thousands of fish specimens in South America. Citizen science in combination with social media has also provided valuable data on the interactions between roe deer and Northern chamois in the Italian Alps (Mori et al. 2018). Such studies indicate the efficacy of social media derived data that span a large temporal and spatial scale.

This study uses data from social media, specifically Facebook, to identify cetacean stranding events associated with marine litter across Southeast Asia and provides insights into cetacean distributions and foraging behaviour in regions where their biology is not well understood.

\section{Methods}

Facebook was used as a source of data on the stranding of cetaceans in Southeast Asia following the methods of Abreo et al. (2019). For the purpose of this study, SE Asia is defined as the ASEAN member states. Despite being landlocked, Lao PDR was still included in the search due to it having a small population of freshwater Irrawaddy dolphins in the Mekong River (Smith 2009). The following keywords were used in the search: Stranding + Whale (or Dolphin) + Country, Plastic Ingestion + Whale (or Dolphin) + Country and Entanglement + Whale (or Dolphin) + Country. Relevant pages were scanned for any strandings of whales or dolphins between the date range 2009 to 2019. Non-English language posts were translated with Google Translate. Posts without photographic evidence or video footage were excluded. Species identification was confirmed using the 'Encyclopedia of Marine Mammals' (Würsig et al. 2009). Because they are very difficult to distinguish purely from photographic evidence, common bottlenose dolphins (Tursiops truncatus) and Indo-Pacific bottlenose dolphins (Tursiops aduncus) were not considered separate in this study. Some specimens were highly decomposed, so identification was not possible. Pages with posts on the same individual were counted as the same data point. Mass strandings (two or more individuals (Aragones et al. 2010)), and the stranding of a mother and calf, were recorded as single stranding events. All information included in the posts was recorded, which included: species (if known and confirmed from the photographic evidence); location; date; cause of death and whether a necropsy was carried out. Locations, such as the name of the beach were converted into approximate GPS coordinates from Google Earth. 


\section{Results}

\section{Species composition}

A total of 163 stranding events were posted on Facebook from 2009 to 2019 in Southeast Asia, which comprised the stranding of 221 individuals (including four mass stranding events). $25 \%$ of strandings $(n=41)$ showed signs of litter interaction (all data in Supplementary Materials). According to the Facebook data, of the estimated 47 cetacean species in Southeast Asian waters (SEAMAM III 2015), 15 species were recorded as stranding for reasons related to plastic (common and Indo-Pacific bottlenose dolphins are counted as one species), therefore, at least $32 \%$ of cetacean species in Southeast Asia are interacting with marine litter. These stranding events involved two mysticetes: a Bryde's whale and an unidentified baleen whale; the remainder were all odontocetes. Seven species were recorded more than once. Species which stranded the most frequently in relation to litter were the Irrawaddy dolphin $(n=6)$, and the pygmy sperm whale (Kogia breviceps) $(n=5)$ (Table 1$)$.

\section{Interaction-type}

Of the total stranding events, $25.2 \%$ were related to marine litter, either ingestion $(56.1 \%)$ or entanglement (41.5\%) (Table 1). There was additionally a single case best categorised as entrapment (a Bryde's whale trapped in a fish corral in the Philippines).

Ingestion in deep divers is much higher in comparison to species that forage closer to the surface, which appear more likely to become entangled (Fig. 1a). 94\% of the plasticrelated strandings involving deep diving species were due to ingestion (including sperm whales, pygmy and dwarf sperm whales, pilot whales and beaked whales), whereas $67 \%$ of strandings of species that forage nearer to the surface resulted from entanglement (Fig. 1b).

\section{Spatial distribution}

Out of the ten countries, the Philippines had the highest frequency of strandings $(n=102)$, with $28.4 \%(n=29)$ in relation to litter. Litter interactions in the Philippines were the most frequent in the Davao region (Region XI) $(n=10)$. Indonesia had the most strandings following the Philippines $(n=20)$, of which four were litter related. The Philippines also had the most species recorded to interact with litter $(n=14)$, followed by Indonesia and Malaysia $(n=4)$. Five countries (Singapore, Myanmar, Vietnam, Brunei and Laos), however, had no Facebook posts on strandings related to litter and Brunei and Laos had no posted strandings at all. Singapore, Brunei and Laos have the three smallest coastlines (Laos being entirely landlocked) and the fewest numbers of Facebook users compared to the other member states. Our study also found Cambodia to have reported three litter-related strandings on Facebook (Table 2; Fig. 2).

\section{Strandings necropsied and litter-types}

The majority of stranding events were not necropsied, with only $22 \%(\mathrm{n}=36)$ reported as being necropsied by a trained professional. $78 \%$ of necropsied individuals had interacted with litter. Malaysia had the highest proportion of strandings necropsied (40\%), followed 


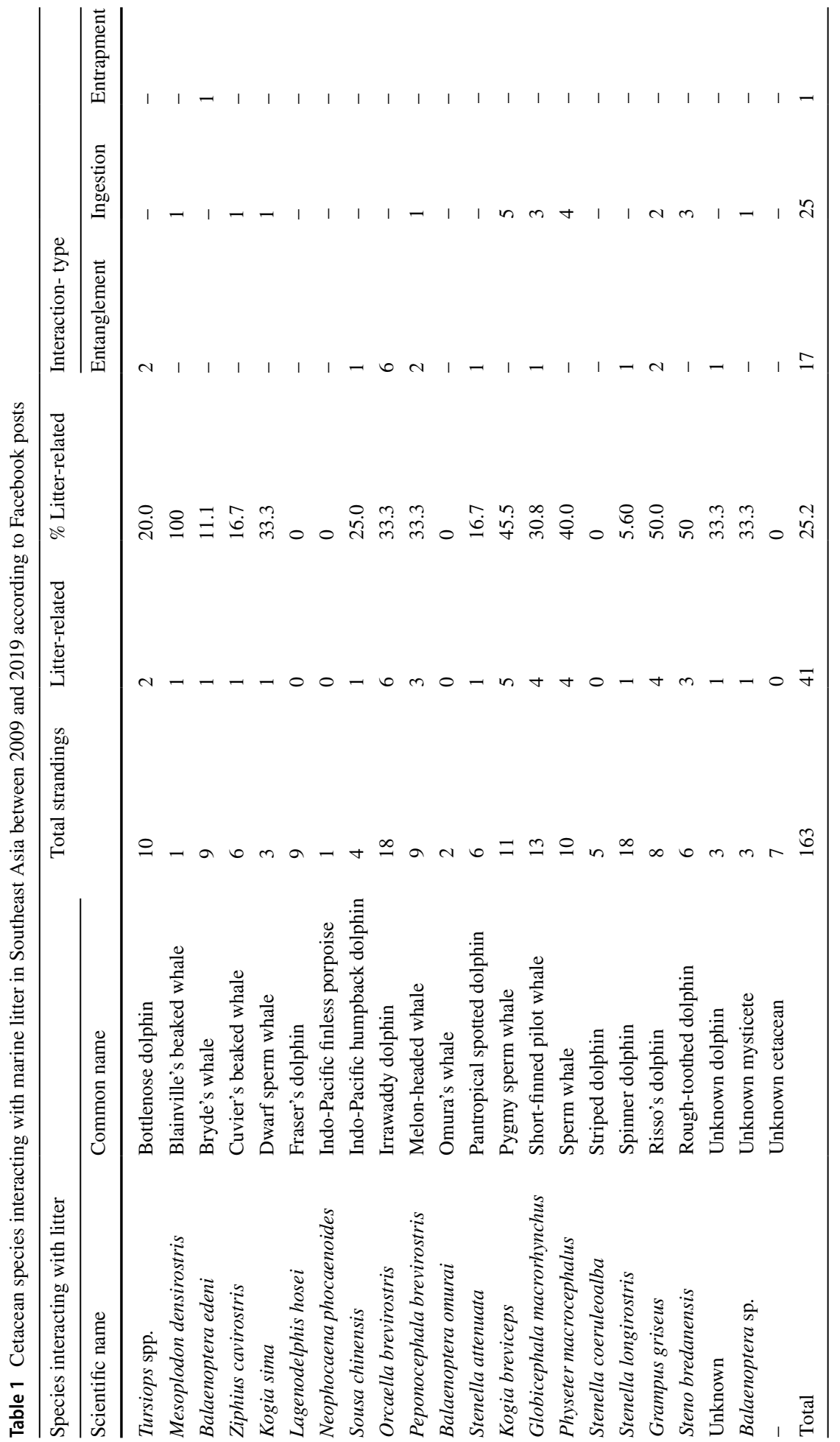



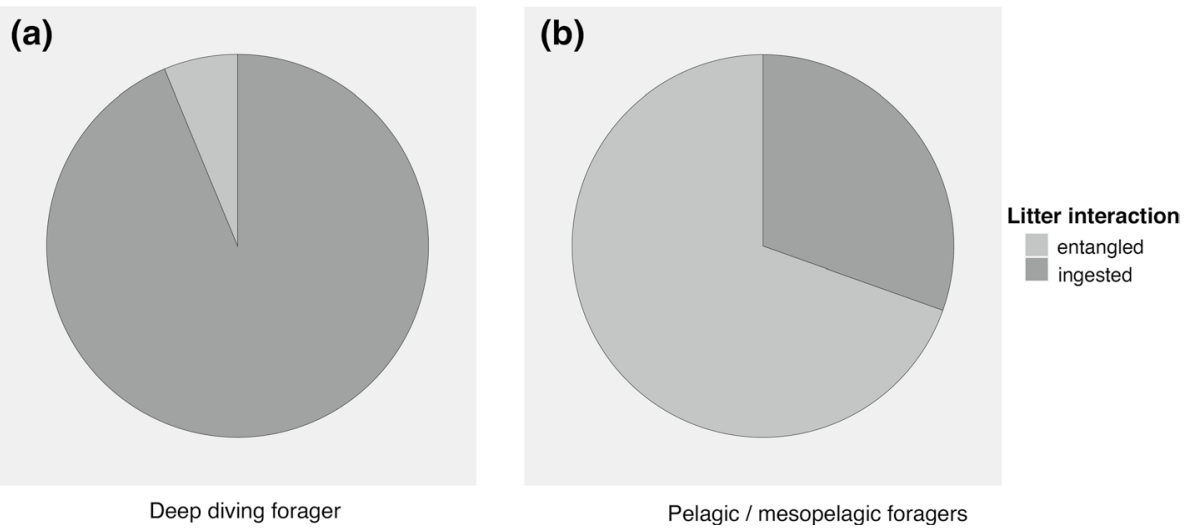

Fig. 1 Strandings, foraging type and type of interaction. (a) The proportion of strandings that ingested litter vs. the proportion that became entangled for species that forage at depths $>1000 \mathrm{~m}$ (deep divers). (b) The proportion of strandings for species that ingested litter vs. the proportion that became entangled that forage in the pelagic zone

by Cambodia (33\%). The Philippines and Thailand, each had 25\% necropsied. Facebook posts in Singapore, Vietnam and Myanmar all had no evidence of necropsies, and so the frequency of ingestion could not be ascertained (Table 2, Fig. 3). The most frequent littertypes found ingested in stranded individuals was plastic bags (23\%), followed by packaging, which included food wrappers and containers (Table 3).

\section{Discussion}

\section{Species composition and types of interaction}

\section{Deep diving foragers and ingestion}

Addressing data gaps on cetacean populations and the threats they are subject to is crucial for their conservation. Seven species were observed to strand more than once throughout the ten-year period, including: sperm whales (Physeter macrophalus), short-finned pilot whales (Globicephala macrorhynchus) and pygmy sperm whales. These were the most common species to strand after the Irrawaddy dolphin, and all are deep diving species. Our results provide insight into the susceptibility of deep diving species to the ingestion of debris.

It is likely that deep diving cetaceans are vulnerable to marine debris because their echolocation cannot differentiate between litter and their prey items when they are in close proximity (Lusher et al. 2015). The pygmy sperm whale was the most frequent deep diving species to experience litter-related strandings which is consistent with the findings of Beatson (2007). The ingestion of plastic by pygmy sperm whales was also reported by (Brentano and Petry 2020) in southern Brazil where ingested plastic bags caused gastric obstruction. Pygmy sperm whales forage on commercially important fish species such as hake (Brentano and Petry 2020), and it has been suggested that they are more likely to 


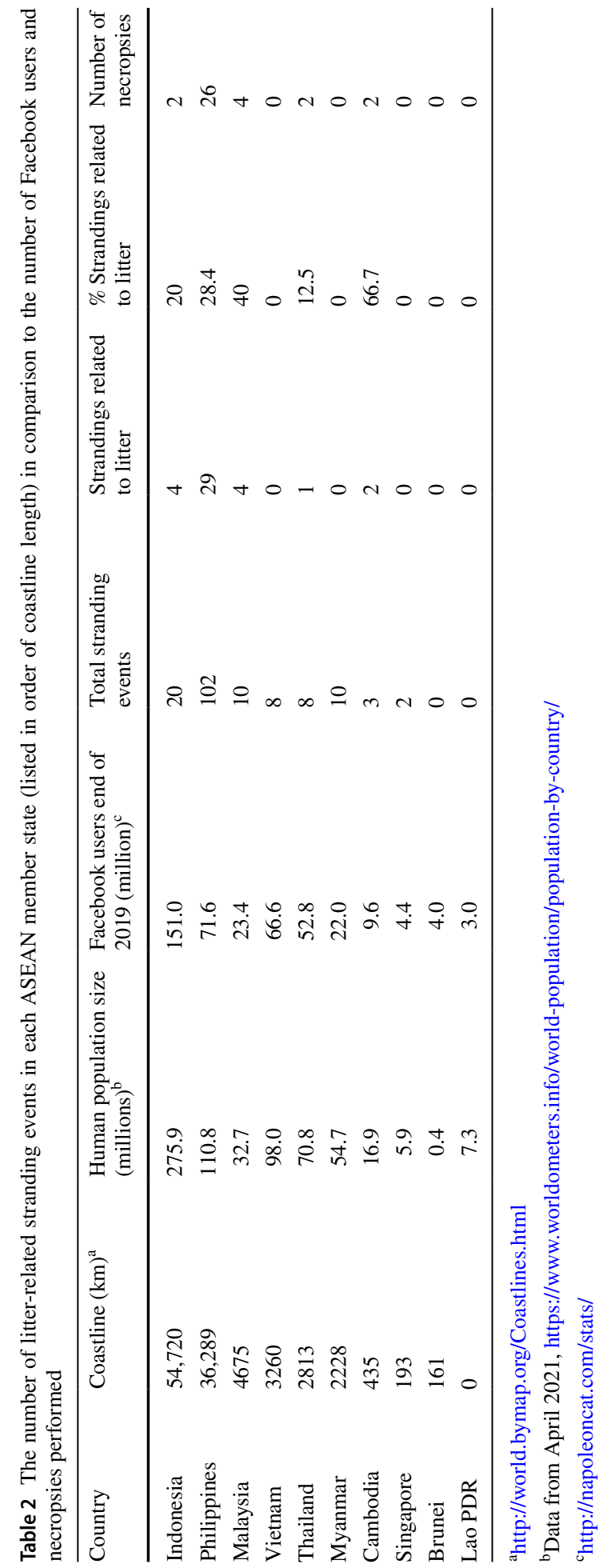




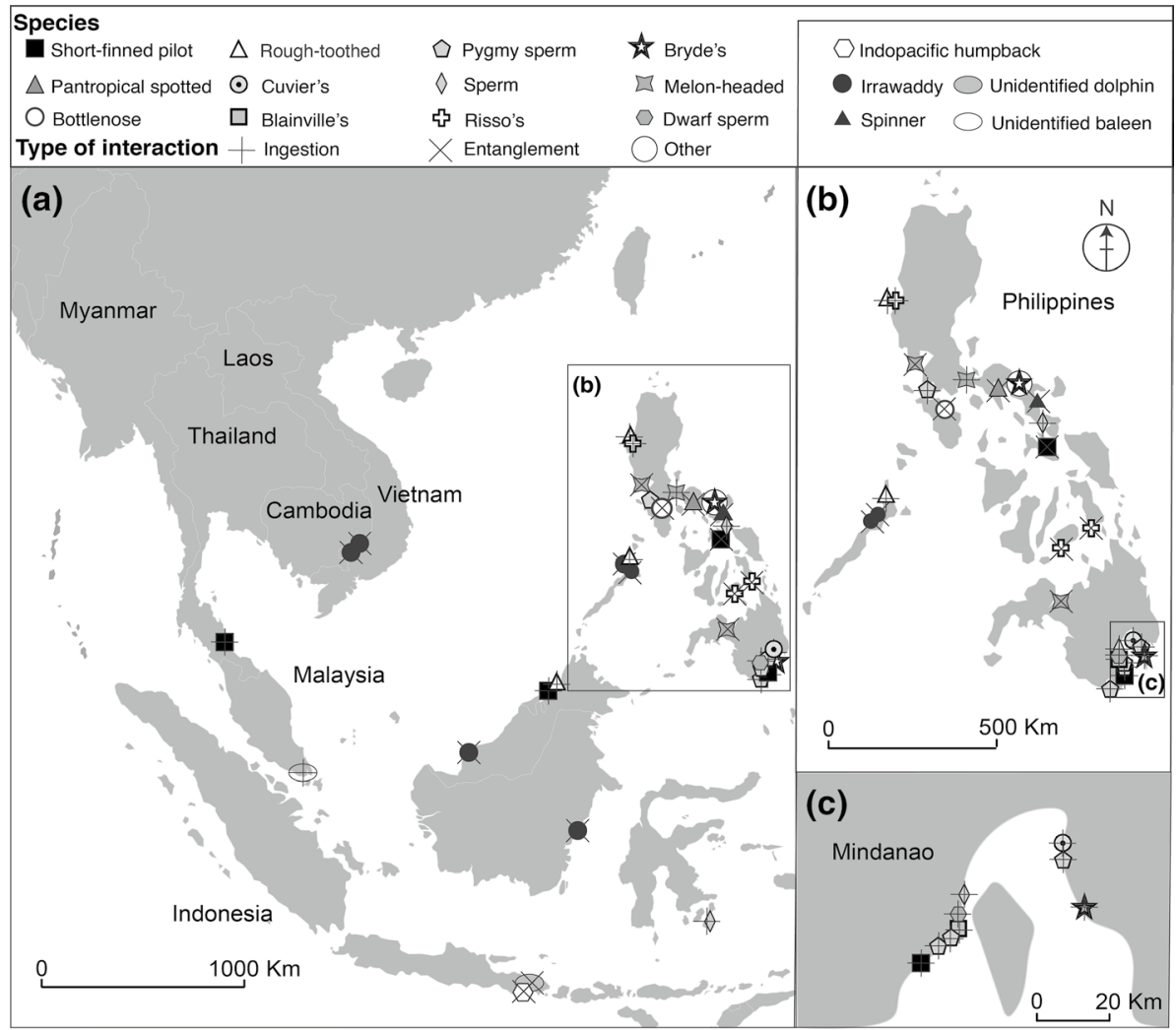

Fig. 2 Locations of stranded cetaceans which had interacted with litter in Southeast Asia 2009-2019 as posted on Facebook. (a) Entire study area and panels show details. (b) Philippines. (c) Mindanao, Philippines

ingest litter due to the depletion of their prey from fishing activities, such as deep-sea trawling (Baird and Hooker 2000).

\section{Epipelagic and mesopelagic foragers and entanglement}

Our study indicates that species that forage in the epipelagic or the mesopelagic zone such as bottlenose dolphins, are more susceptible to entanglement in marine debris. This is consistent with Obusan et al. (2016), who found that bottlenose dolphins often become entangled in drift gillnets in the Philippines. Species that spend more time near the surface may be at risk of entanglement because of their 'playful' behaviour and curiosity which means that they often investigate novel objects in their environment, such as floating plastic debris (Mattlin and Cawthorn 1986; Laist 1987). Bycatch in small-scale fisheries in Southeast Asia is also a serious threat to cetaceans that forage nearer to the surface (Reeves 2003). Our study is likely to reveal less evidence of bycatch due to these incidences being not reported as a result of the negative consequences of doing so publicly on Facebook. Entanglement cases were much less frequent in this study in comparison to ingestion, which was unexpected since entanglement is more visible and does not need to be revealed by 


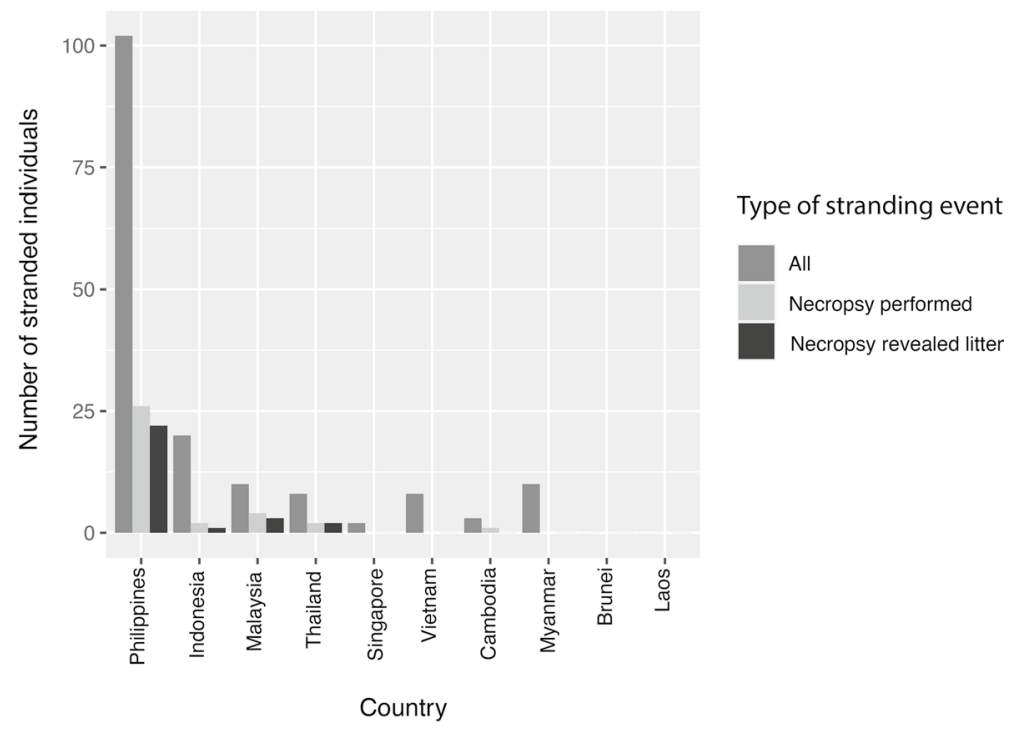

Fig. 3 The number of stranding events compared to the number of individuals necropsied and the number of necropsies that found litter

Table 3 Types of litter found ingested by stranded cetaceans in the study following necropsy

\begin{tabular}{lc}
\hline Litter-type & $\begin{array}{l}\text { Ingestion } \\
\text { cases (\%) }\end{array}$ \\
\hline Plastic bags & 22.9 \\
Packaging & 20.0 \\
Fishing gear & 11.4 \\
Metal & 11.4 \\
Plastic sheet & 0.06 \\
Rubber & 0.06 \\
Other & 22.9 \\
\hline
\end{tabular}

necropsy (Kühn et al. 2015). The low frequency of entanglement cases contrasts with Gall and Thompson (2015), whose review identified more entanglement than ingestion cases globally. Three species, the melon-headed whale (Peponocephala electra), the Risso's dolphin (Grampus griseus), and the short-finned pilot whale were recorded as both ingesting and becoming entangled in litter. This may be due to these species having lifestyles that are quite versatile with reference to their distribution throughout the water column. Pilot whales, although being categorised as deep divers in this study, nevertheless spend $60 \%$ of their time near the water surface, putting themselves at risk of entanglement (HeideJørgensen et al. 2002). The melon-headed whale and Risso's dolphin, although counted as surface foragers here, can, however dive to depths in excess of $300 \mathrm{~m}$ (West et al. 2018; Arranz et al. 2019). 


\section{The Irrawaddy dolphin}

In this study, the most frequent species to experience litter-related strandings was the Irrawaddy dolphin which is found in coastal, lacustrine and riverine waters throughout Asia (Stacey and Arnold 1999). Each litter-related stranding involved entanglement in fishing gear. In Southeast Asia subsistence and commercial fisheries are extensive, and accidental bycatch in gillnets remains a significant threat to river dolphin populations (Lewison et al. 2004). The riverine populations include the Mekong River (Cambodia, Lao PDR and Vietnam), the Mahakam River (Indonesia) and the Ayeyarwady River (Myanmar). Irrawaddy dolphins as a species are now classified as Endangered by the IUCN, but freshwater populations that are isolated from the marine environment, face greater threat than their marine counterparts. Such freshwater populations, together with those in the Malampaya Sound in the Philippines, are considered Critically Endangered (Minton et al. 2017).

The Mekong River Irrawaddy dolphins are genetically distinct from the other riverine populations, possibly representing a subspecies (Beasley et al. 2005). Preserving the existing genetic diversity is a high priority to ensure long-term survival of the species (Krützen et al. 2018). As a result, the establishment of protected areas with no gillnet fishing have been recently implemented for the conservation of the dolphin in Cambodia. These areas are enforced by the Mekong River Guard Program. The program is thought to be a significant factor in the recent increase in calf survival but the authorities need to ensure that illegal fishermen are successfully prosecuted to achieve the goal of zero dolphin mortality caused by fishing (Limsong et al. 2017).

Of the six Irrawaddy dolphin litter-related strandings recorded from the Facebook search, two were in the Malampaya Sound (Philippines), one by the Mahakam River (Indonesia), two by the Mekong River (Cambodia) and one by the Batang Matu River, in Sarawak in Malaysia. All strandings of this species in the Philippines were recorded as a result of entanglement in discarded fishing nets, and all other posts appeared to be bycatch according to the text and images in the post. These results further emphasise that freshwater populations of Irrawaddy dolphins are more vulnerable than those in marine areas, and that entanglement in gill nets is still a substantial threat. The Sarawak stranding is of particular interest because the presence of Irrawaddy dolphins in this location is less well documented, this highlights a key knowledge gap in the species' distribution which needs to be addressed to establish a better system for assessing and mitigating bycatch. River mouths are known to accumulate plastics, particularly during periods of low freshwater discharge (van Emmerik et al. 2020), making Irrawaddy dolphins particularly vulnerable at certain periods of the year. Whilst this study has aided understanding of the Irrawaddy dolphin's spatial distribution, there has been no range-wide survey and further assessments of population dynamics are required for effective long-term management.

\section{Spatial distribution and litter-related stranding hotspots}

\section{The Philippines as a stranding hotspot}

Our results show spatial variability in the frequency of litter-related cetacean strandings throughout Southeast Asia, with the Philippines having the most litter-related strandings posted on Facebook. Such variation could suggest differences in either the distribution of marine debris or cetacean species richness. Alternatively, it is possible that differences are 
due to recording biases. The high frequency of stranding reports in the Philippines could also be due to the country having a vast coastline $(36,289 \mathrm{~km}$, with more than 7100 islands (Fajardo 2001)). The Philippines also has significant mismanaged waste in global terms; Jambeck et al. (2015) estimated that this country contributes between 0.28 and 0.75 million metric tons of plastic to the marine environment per year. In terms of percentage of mismanaged waste, however, the Philippines (83\%) is lower than in other ASEAN member states such as Myanmar (89\%) and Vietnam (88\%). Therefore, it is possible that the higher number of Facebook users in the Philippines compared to the other countries (excluding Indonesia) contributes to higher levels of reporting. Moreover, the Philippines has Facebook pages specifically for reporting the stranding of marine mammals, leading to higher reporting. For example, the Facebook page 'Philippine Marine Mammal Stranding Network' (PMMSN) was an efficient source of data. The formation of the PMMSN and the training of Bureau of Fisheries and Aquatic Resources (BFAR) personnel on the response to marine mammal strandings led to the development of local response teams which substantially increased effort for recording and responding to stranding events (Aragones et al. 2010). Stranding events related to marine debris in the Philippines were particularly frequent in the Davao region, around Davao City, in agreement with the findings of Abreo et al. (2019). Davao City is the largest city in the Philippines and is the third-most populous after Quezon City (which has no coastline) and Manila (Mercado 1998). Therefore, the chances of a stranding being observed are high. It is also possible, however, that Davao is a stranding hotspot (Aragones et al. 2010).

\section{Strandings in Indonesia}

After the Philippines, Indonesia had most stranding events posted on Facebook. Indonesia has a large coastline $(54,720 \mathrm{~km})$ and number of Facebook users both greater than the Philippines. Nevertheless, Indonesia had five times fewer recorded stranding events than the Philippines. The Philippines however, has a much larger population density (368 people per $\mathrm{km}^{2}$ compared to 151 people per $\mathrm{km}^{2}$ for Indonesia) (www.worldometers.info), possibly contributing to better reporting. Jambeck et al. (2015) estimated that Indonesia is the second biggest contributor of plastics to the ocean in Southeast Asia. However, research has focused on this problem and possible solutions have been developed. For example, Indonesia is the only country in the world that has established its own National Action Plan on Marine Debris (2017-2025). The application of technology to control plastic debris, such as using plastic waste as a raw material in the construction of asphalt roads is a focus of research (The Government of the Republic of Indonesia 2017). The plan also emphasises the importance of societal efforts to reduce and recycle plastic. The fewer reported strandings in Indonesia does not necessarily reflect that cetaceans are less severely impacted by litter than those in Philippine waters. Rather, the success of the PMMSN highlights the need for similar networks to be established in the other ASEAN member states.

\section{Litter-related strandings in other ASEAN member states}

As noted, Singapore, Vietnam, Myanmar, Laos, and Brunei all had no Facebook posts regarding litter-related cetacean strandings; however, this does not necessarily indicate that cetaceans are not interacting with marine debris in these locations. Singapore, Brunei and Laos have the three smallest coastlines and the fewest number of Facebook users which reduces the chance of strandings and reportings; although Singapore, being a particularly 
small state, has the largest population density out of all the ASEAN members (7866 people per $\mathrm{km}^{2}$ ) (www.statista.com, accessed November 2019). Cetaceans in Vietnam have cultural importance and so coastal communities have made efforts to reduce bycatch, such as regulating the use of untended gillnets (SEAMAM III 2015), which could partly explain the absence of entanglement cases posted. Despite no evidence of cetaceans interacting with plastic on Facebook in five of the member states or from published literature, this impact still poses a substantial risk due to the volumes of waste generated and mismanaged in these countries. Much of the waste is released into marine or riverine environments, and more widespread monitoring urgently needed (Ngoc and Schnitzer 2009; Jambeck et al. 2015).

\section{Strandings necropsied and litter-types ingested in Southeast Asia}

The majority of cetacean strandings were not investigated further and necropsied after death. In the case of Vietnam, this is perhaps due to the country's whale worship tradition, fishermen believe that they protect them at sea (a local concept that embraces all cetaceans). Vietnamese believe that cetaceans intentionally beach themselves and they give them funerals and burials without investigating why the animals stranded (Ruddle 1998). Cetaceans elsewhere in Southeast Asia are generally considered to be competitors for fish and there is consequently a lack of awareness of their conservation status and ecological importance, such as being considered sentinel species (SEAMAM III 2015). The small number of necropsies conducted throughout Southeast Asia suggests that the problem of litter ingestion may be much higher than this study predicts -particularly since $78 \%$ of the necropsies carried out found litter in the stomachs of the individuals. There were species that stranded regularly throughout the ten-year period in this study, but with little or no information on the cause of death. For example, 18 spinner dolphin (Stenella longirostris) strandings were recorded, but none were necropsied-this species could be negatively impacted by ingested marine debris and further research is warranted (one case of entanglement was reported). The majority of the entanglement cases were not necropsied; presumably because entanglement was assumed to be the cause of death. It should also be recognised that an animal could have become entangled post-mortem, so an accurate assessment of cause of death is very difficult. Furthermore, an entangled individual could have also ingested litter which can only be determined by necropsy. Our study highlights the need for training in necropsy protocols to determine the main threats to cetacean populations (Mustika et al. 2009).

\section{Litter composition}

A major challenge in addressing marine debris is the diverse nature of litter products, and the variety of routes they can follow to enter the marine environment (Pruter 1987; Ryan et al. 2009). Data retrieved from this study provide insight into the potential origin of the litter that cetaceans are ingesting. For example, photos posted on Facebook show the brands of litter found in the stomachs of stranded individuals (Fig. 4A and B). These photographs are important because they allow the litter to be traced back to the manufacturer.

Studies suggest that most macro-litter found in the ocean is either plastic bags or packaging (Di-Méglio and Campana 2017; Castro-Jiménez et al. 2019) and the most common litter-types found ingested in stranded individuals in our study were indeed plastic bags, followed by packaging. 

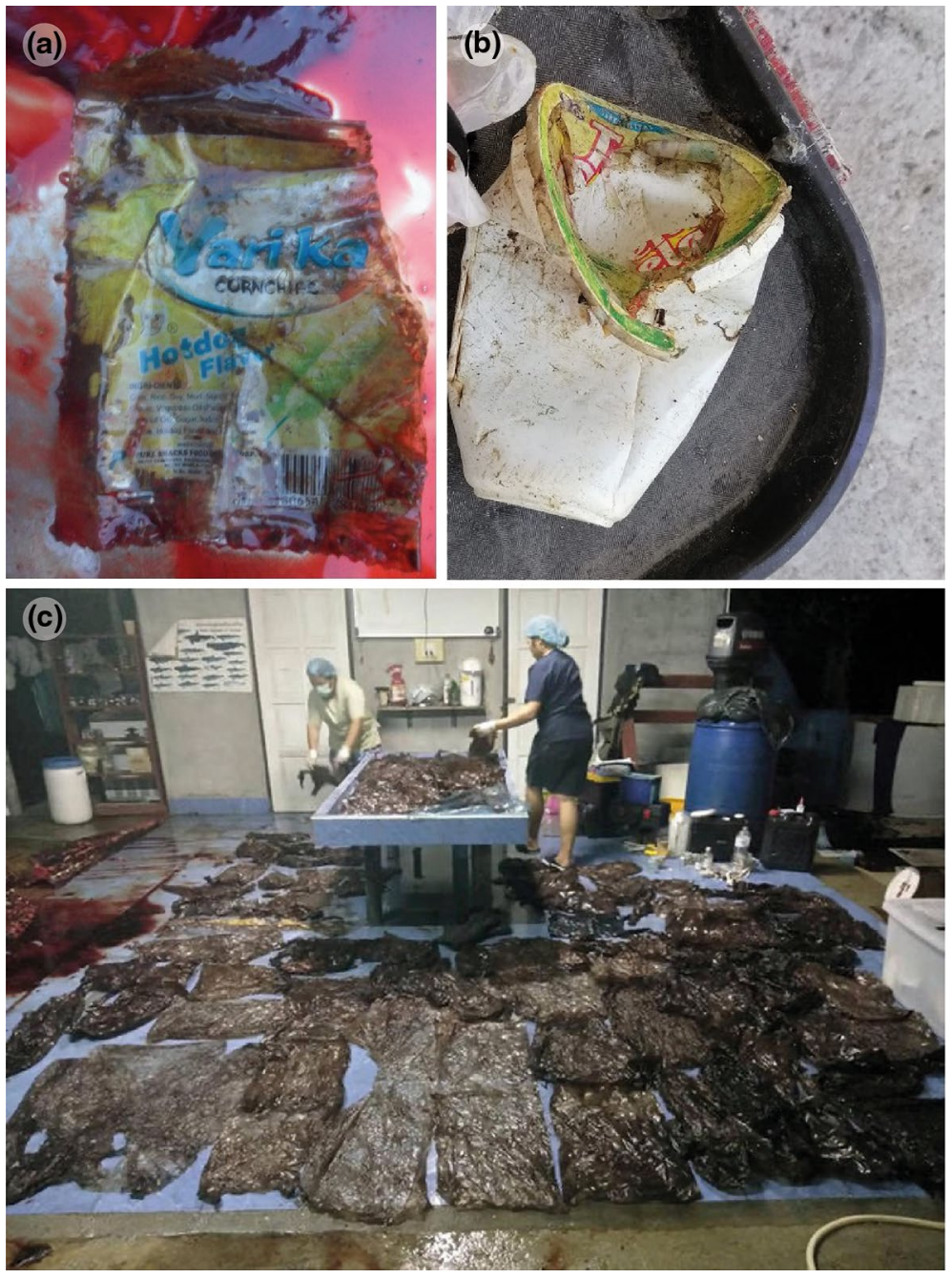

Fig. 4 Photographic images retrieved from the Facebook pages 'Marine Wildlife Watch of the Philippines' and 'Cetal Fauna', showing brands of litter ingested. (a) Recovered from a dwarf sperm whale in 2014, Philippines. Photo credit: Darrell Blatchley, D’Bone Collector Museum Inc. (b) Recovered from a sperm whale in 2019, Philippines. (c) Plastic ingested by a short-finned pilot whale in 2018, Songkhla, Thailand

In 2018, 80 plastic bags were found in a short-finned pilot whale in Songkhla, Thailand (Fig. 4C). Plastic bags have been highlighted as significant sources of pollution in other studies, for example, accounting for $27 \%$ of total beach litter during a study of 23 islands in Jakarta Bay, Indonesia (Willoughby et al. 1997). Management schemes should therefore be established to reduce plastic bag use, such as charges for the bags or taxes on stores that sell them (Xanthos and Walker 2017). The United Kingdom for example, introduced a successful five pence plastic bag charge, which led to six billion fewer bags being issued during the first year of implementation (United Kingdom Department for Environment, Food and Rural Affairs 2015). In a positive development in Davao, non-biodegradable plastic 
bags have been banned (Somera et al. 2013); although biodegradable plastic can still take up to three years to completely break down (Nakum et al. 2011). Biodegradable plastic bags have been found in the gastrointestinal tracts of sea turtles, and therefore have the potential to still cause harm (Müller et al. 2012). It is also important to note that the litter found in Southeast Asian waters may not all originate from Southeast Asian countries, and, therefore, international cooperation is essential (Jambeck et al. 2015).

\section{Conclusions and recommendations}

Our study shows that the use of social media is an effective tool for assessing the impact of marine debris on cetaceans. Facebook has provided information on litter-related stranding hotspots and our research serves as a baseline for the wide-reaching impacts of litter. The numbers of cetacean species negatively affected by litter presented in this study highlights the urgent need to investigate stranding events further, with better cetacean response and improved facilities and training to enable more necropsies. However, priority should be focussed on global and local governance responses to effectively manage the volume of waste before it enters the marine environment.

The small sample size makes it harder to assess any trends, and there is a bias of data towards countries which have stranding networks. Nevertheless, there is still an indication that management actions should be focussed around stranding hotpots such as the Davao region of the Philippines. In addition, there are many confounding biases surrounding stranding rates due to prevailing currents, accessibility of the coastline, numbers of beach users (including residents and tourists), reporting rates and, in our study, numbers of social media users. Our study was, therefore, designed to provide qualitative information on species, distributions and types of interaction with litter, as well as providing a useful method for others to build upon.

Our study is limited in that it is hard to assess the efficiency of science based on social media data in comparison to published literature and other records. Also, some governmental organisations may only have hard copies of stranding data that cannot be accessed online. The small sample size of the results from Facebook can be overcome by gathering data from other social media sites such as Twitter and/or other emerging tools including facepy, a python-based platform, or Rfacebook, Google Social Search, Social Searcher, rtweet, UVRX or Dataoryx. We suggest that a specific global reporting platform for strandings using the combined data from various social media sites would be an invaluable tool to fill key knowledge gaps on litter and marine megafauna. Our study provides a blueprint for such a platform which could include other marine megafauna species, such as sea turtles which are known to be the most vulnerable to plastic debris (Schuyler et al. 2014). Data can be compiled more efficiently through accessing the API (Application Programming Interface) of social media platforms, which will allow data to be available immediately after posting. This extension could help build a more complete picture of marine debris at the global-level. The known impacts of litter on cetaceans are likely to be just the tip of the iceberg, therefore, the more stranding events that are reported and necropsied the more we can learn about the status of cetacean populations and the threats they face.

Supplementary Information The online version contains supplementary material available at https://doi. org/10.1007/s10531-021-02196-6. 
Acknowledgements The authors thank the many citizen scientists, local communities and groups that have taken time to report and document strandings in remote regions, without their dedication and time this research would not have been possible. We also thank the two anonymous reviewers who gave valuable comments which greatly improved the manuscript.

Author contributions KFT and NAS conceived the study, AC carried out the analyses and wrote the first draft of the manuscript. The text, analyses, table, and Figs were prepared by AC, and internally edited and reviewed by RPE, NAS and KFT.

Funding This research was carried out as part of AC undergraduate research and no funding was required.

Data availability All data generated or analysed during this study are included in this published article and its supplementary information file.

\section{Declarations}

Conflict of interest The submitted work was not carried out in the presence of any personal, professional or financial relationships.

Open Access This article is licensed under a Creative Commons Attribution 4.0 International License, which permits use, sharing, adaptation, distribution and reproduction in any medium or format, as long as you give appropriate credit to the original author(s) and the source, provide a link to the Creative Commons licence, and indicate if changes were made. The images or other third party material in this article are included in the article's Creative Commons licence, unless indicated otherwise in a credit line to the material. If material is not included in the article's Creative Commons licence and your intended use is not permitted by statutory regulation or exceeds the permitted use, you will need to obtain permission directly from the copyright holder. To view a copy of this licence, visit http://creativecommons.org/licenses/by/4.0/.

\section{References}

Abreo NAS, Macusi ED, Blatchley DD, Cuenca-Ocay G (2016) First evidence of plastic ingestion by the rare Deraniyagala's beaked whale (Mesoplodon hotaula). IAMURE Int J Ecol Conserv 19:16-36

Abreo NAS, Thompson FK, Arabejo GFP, Superio MDA (2019) Social media as a novel source of data on the impact of marine litter on megafauna: the Philippines as a case study. Mar Pollut Bull 140:51-59. https://doi.org/10.1016/j.marpolbul.2019.01.030

Aragones LV, Roque MA, Flores MB, Encomienda RP, Laule GE, Espinos BG, Maniago FE, Diaz GC, Alesna EB, Braun RC (2010) The Philippine marine mammal strandings from 1998 to 2009: animals in the Philippines in peril? Aquat Mamm 36:219-233. https://doi.org/10.1578/AM.36.3.2010.219

Arranz P, Benoit-Bird KJ, Friedlaender AS, Hazen EL, Goldbogen JA, Stimpert AK, DeRuiter SL, Calambokidis J, Southall BL, Fahlman A, Tyack PL (2019) Diving behavior and fine-scale kinematics of free-ranging Risso's dolphins foraging in shallow and deep-water habitats. Front Ecol Evol 7:53. https://doi.org/10.3389/fevo.2019.00053

Baird IG, Beasley IL (2005) Irrawaddy dolphin Orcaella brevirostris in the Cambodian Mekong River: an initial survey. Oryx 39:301-310. https://doi.org/10.1017/S003060530500089X

Baird RW, Hooker SK (2000) Ingestion of plastic and unusual prey by a juvenile harbour porpoise. Mar Pollut Bull 40:719-720. https://doi.org/10.1016/S0025-326X(00)00051-5

Beasley I, Robertson KM, Arnold P (2005) Description of a new dolphin, the Australian snubfin dolphin Orcaella heinsohni sp. N. (Cetacea, Delphinidae). Mar Mamm Sci 21:365-400. https://doi.org/10. 1111/j.1748-7692.2005.tb01239.x

Beatson E (2007) The diet of pygmy sperm whales, Kogia breviceps, stranded in New Zealand: implications for conservation. Rev Fish Biol Fish 17:295-303. https://doi.org/10.1007/s11160-007-9039-9

Bik HM, Goldstein MC (2013) An introduction to social media for scientists. PLoS Biol 11:e1001535. https://doi.org/10.1371/journal.pbio.1001535

Brentano R, Petry MV (2020) Marine debris ingestion and human impacts on the pygmy sperm whale (Kogia breviceps) in Southern Brazil. Mar Pollut Bull 150:110595. https://doi.org/10.1016/j.marpo lbul.2019.110595 
Bryant D, Burke L, McManus J, Spalding M (1998) Reefs at Risk. A map-based indicator of threats to the world's coral reefs. Washington, DC: World Resources Institute. International Center for Living Aquatic Resources Management, World Conservation Monitoring Centre, and the UN Environmental Programme

Castro-Jiménez J, González-Fernández D, Fornier M, Schmidt N, Sempéré R (2019) Macro-litter in surface waters from the Rhone River: plastic pollution and loading to the NW Mediterranean Sea. Mar Pollut Bull 146:60-66. https://doi.org/10.1016/j.marpolbul.2019.05.067

Day RH, Wehle DHS, Coleman FC (1985) Ingestion of plastic pollutants by marine birds. In: Proceedings of the workshop on the fate and impact of marine Debris. US Dep Commer, NOAA Tech. Memo, NMFS. NOAA-TM-NMFS-SWFC-54 2:344-86

de Stephanis R, Giménez J, Carpinelli E, Gutierrez-Exposito C, Cañadas A (2013) As main meal for sperm whales: plastics debris. Mar Pollut Bull 69:206-214. https://doi.org/10.1016/j.marpolbul.2013.01.033

Di-Méglio N, Campana I (2017) Floating macro-litter along the Mediterranean French coast: composition, density, distribution and overlap with cetacean range. Mar Pollut Bull 118:155-166. https://doi.org/10. 1016/j.marpolbul.2017/02.026

Fajardo IS (2001) Surveying and mapping in the Philippines. In: proceedings of the twentieth international cartographic conference. dev.icaci.org. https://dev.icaci.org/files/documents/national_reports/19992003/Philippines.pdf

Galgani F, Fleet D, Van Franeker J, Katsanevakis S, Maes T, Mouat J, Oosterbaan L, Poitou I, Hanke G, Thompson R, Amato E, Birkun A, Janssen C (2010) Marine strategy framework directive- Task Group 10 report. Marine Litter. JRC Scientific and Technical Reports. N. Zampoukas (ed) EUR 24340 EN-2010

Gall SC, Thompson RC (2015) The impact of debris on marine life. Mar Pollut Bull 92:170-179. https:// doi.org/10.1016/j.marpolbul.2014.12.041

Heide-Jørgensen MP, Bloch D, Stefansson E, Mikkelsen B, Ofstad LH, Dietz R (2002) Diving behaviour of long-finned pilot Whales Globicephala melas around the Faroe Islands. Wildl Biol 8:307-313. https:// doi.org/10.2981/wlb.2002.020

Jambeck JR, Geyer R, Wilcox C, Siegler TR, Perryman M, Andrady A, Narayan R, Law KL (2015) Marine pollution. Plastic waste inputs from land into the ocean. Science 347:768-771. https://doi.org/10.1126/ science. 1260352

Jefferson TA, Smith BD, Braulik GT, Perrin W (2017) Sousa chinensis (errata Version Published in 2018). The IUCN Red List of Threatened Species: E. T82031425A123794774. https://doi.org/10.2305/IUCN. UK.2017-3.RLTS.T82031425A50372332.EN

Kreb D, Reeves RR, Thomas PO, Braulik GT, Smith BD (2010) Establishing protected areas for Asian freshwater cetaceans: freshwater cetaceans as flagship species for integrated river conservation management, Samarinda, 19-24 October 2009. In: Final Workshop Report. Yayasan Konservasi RASI, Samarinda, Indonesia. by Yayasan Konservasi RASI/Conservation Foundation for Rare Aquatic Species http://www.readbag.com/iucn-csg-wp-content-uploads-2010-03-final-asian-freshwater-dolphinworkshop-report

Krützen M, Beasley I, Ackermann CY, Lieckfeldt D, Ludwig A, Ryan GE, Bejder L, Parra GJ, Wolfensberger R, Spencer PBS (2018) Demographic collapse and low genetic diversity of the Irrawaddy dolphin population inhabiting the Mekong River. PLoS ONE 13:e0189200. https://doi.org/10.1371/journ al.pone. 0189200

Kühn S, Rebolledo ELB, van Franeker JA (2015) Deleterious effects of litter on marine life. In: Bergmann M Gutow L, Klages L M (eds) Marine anthropogenic litter, Springer, New York, pp 75-116. https:// doi.org/10.1007/978-3-319-16510-3_4

Laist DW (1987) Overview of the biological effects of lost and discarded plastic debris in the marine environment. Mar Pollut Bull 18:319-326. https://doi.org/10.1016/S0025-326X(87)80019-X

Laist DW (1997) Impacts of marine debris: entanglement of marine life in marine debris including a comprehensive list of species with entanglement and ingestion records. In: Coe JM, Rogers DB (eds) Marine Debris: sources, impacts, and solutions. Springer, New York, pp 99-139

Lasut MT, Weber M, Pangalila F, Rumampuk NDC, Rimper JRTSL, Warouw V, Kaunang ST, Lott C (2018) From coral triangle to trash triangle-how the hot spot of global marine biodiversity is threatened by plastic waste. In: , Cocca M, Di Pace E, Errico M, Gentile G, Montarsolo A, Mossotti R (eds) Proceedings of the International conference on microplastic pollution in the Mediterranean Sea. Springer, Cham, pp 107-113. https://doi.org/10.1007/978-3-319-71279-6_15

Lewison RL, Crowder LB, Read AJ, Freeman SA (2004) Understanding impacts of fisheries bycatch on marine megafauna. Trends Ecol Evol 19:598-604. https://doi.org/10.1016/j.tree.2004.09.004

Limsong HS, Ath MCS, Thomas P, Smith MB, Director WCS (2017) Report of the international workshop on the conservation of irrawaddy dolphins in the mekong river. https://iucn-csg.org/wp-content/uploa 
ds/2010/03/Report-of-the-2017-International-Workshop-on-the-Conservation-of-Irrawaddy-Dolphinsin-the-Mekong-River.pdf

Lusher AL, Hernandez-Milian G, O’Brien J, Berrow S, O’Connor I, Officer R (2015) Microplastic and macroplastic ingestion by a deep diving, oceanic cetacean: the True's beaked whale Mesoplodon mirus. Environ Pollut 199:185-191. https://doi.org/10.1016/j.envpol.2015.01.023

Lyons Y, Linting TS, Neo ML (2019) A review of research on marine plastics in Southeast Asia. https://cil. nus.edu.sg/wp-content/uploads/2019/07/A-review-of-research-on-marine-plastics-in-Southeast-Asia_ Final28June2019Rev4July2019.pdf

Mattlin RH, Cawthorn MW (1986) Marine debris—an international problem. N Z Environ 51:3-6

Mercado RG (1998) In search of metropolitan definitions: lessons from Metro Davao. PIDS discussion paper series NO. 98-29. https://www.econstor.eu/handle/10419/187371

Minton G, Smith BD, Braulik GT, Kreb D, Sutaria D, Reeves R (2017) Orcaella brevirostris (errata Version Published in 2018). The IUCN Red List of Threatened Species 2017: E. T15419A123790805. https:// doi.org/10.2305/IUCN.UK.2017-3.RLTS

Moore CJ (2008) Synthetic polymers in the marine environment: a rapidly increasing, long-term threat. Environ Res 108:131-139. https://doi.org/10.1016/j.envres.2008.07.025

Mori E, Di Bari P, Coraglia M (2018) Interference between roe deer and northern chamois in the Italian alps: are Facebook groups effective data sources? Ethol Ecol Evol 30:277-284. https://doi.org/10. $1080 / 03949370.2017 .1354922$

Müller C, Townsend K, Matschullat J (2012) Experimental degradation of polymer shopping bags (standard and Degradable Plastic, and Biodegradable) in the gastrointestinal fluids of sea turtles. Sci Total Environ 416:464-467. https://doi.org/10.1016/j.scitotenv.2011.10.069

Mustika PL, Hutasoit P, Madusari CC, Purnomo FS, Setiawan A, Tjandra K, Prabowo WE (2009) Whale strandings in Indonesia, including the first record of a humpback whale (Megaptera novaeangliae) in the archipelago. Raffles B Zool 57:199-206

Nakum AN, Patel MN, Patel PR, Patel VR (2011) Biodegradable polymers: an ecofriendly approach in newer millennium. Asian J Biomed Pharm 1:23-39

Nelms SE, Duncan EM, Broderick AC, Galloway TS, Godfrey MH, Hamann M, Lindeque PK, Godley BJ (2015) Plastic and Marine Turtles: a review and call for research. ICES J Mar Sci 73:165-181. https:// doi.org/10.1093/icesjms/fsv165

Ngoc UN, Schnitzer H (2009) Sustainable solutions for solid waste management in Southeast Asian countries. J Waste Manag 29:1982-1995. https://doi.org/10.1016/j.wasman.2008.08.031

Obusan MCM, Rivera WL, Siringan MAT, Aragones LV (2016) Stranding events in the Philippines provide evidence for impacts of human interactions on cetaceans. Ocean Coast Manag 134:41-51. https://doi. org/10.1016/j.ocecoaman.2016.09.021

Poeta G, Staffieri E, Acosta ATR, Battisti C (2017) Ecological effects of anthropogenic litter on marine mammals: a global review with a 'black-list' of impacted taxa. Hystrix 28:253-264. https://doi.org/10. 4404/hystrix-00003-2017

Provencher JF, Bond AL, Avery-Gomm S, Borrelle SB, Bravo Rebolledo EL, Hammer S, Kühn S, Lavers JL, Mallory ML, Trevail A, van Franeker JA (2017) Quantifying ingested debris in marine megafauna: a review and recommendations for standardization. Anal Methods 9:1454-1469. https://doi.org/10. 1039/C6AY02419J

Pruter AT (1987) Sources, quantities and distribution of persistent plastics in the marine environment. Mar Pollut. Bull 18:305-310. https://doi.org/10.1016/S0025-326X(87)80016-4

Reeves RR, Smith BD, Crespo EA, Nortabartolo di Sciara G (2003) Dolphins, whales and porpoises: 20022010 conservation action plan for the world's cetaceans. IUCN/SSC Cetacean Specialist Group. IUCN, Gland, Switzerland and Cambridge, UK.ix+139

Ruddle K (1998) Traditional community-based coastal marine fisheries management in Viet Nam. Ocean Coast Manag 40:1-22. https://doi.org/10.1016/S0964-5691(98)00072-6

Ryan PG (1987) The incidence and characteristics of plastic particles ingested by seabirds. Mar Environ Res 23:175-206. https://doi.org/10.1016/0141-1136(87)90028-6

Ryan PG, Moore CJ, van Franeker JA, Moloney CL (2009) Monitoring the abundance of plastic debris in the marine environment. Philos Trans R Lond Biol 364:1999-2012. https://doi.org/10.1098/rstb.2008. 0207

Ryan PG (2015) How quickly do albatrosses and petrels digest plastic particles? Environ Pollut 207:438440. https://doi.org/10.1016/j.envpol.2015.08.005

Schuyler QA, Wilcox C, Townsend K, Hardesty BD, Marshall NJ (2014) Mistaken identity? Visual similarities of marine debris to natural prey items of sea turtles. BMC Ecol 14:14. https://doi.org/10.1186/ 1472-6785-14-14 
SEAMAM III (2015) Report of the third Southeast Asian marine mammal symposium. UNEP/CMS Secretariat. Technical Series No. 32

Sidlauskas B, Bernard C, Bloom D, Bronaugh W, Clementson M, Vari RP (2011) Life in science Ichthyologists Hooked on Facebook. Science 332:537. https://doi.org/10.1126/science.332.6029.537-c

Smith BD (2009) Irrawaddy dolphin: Orcaella brevirostris. In: Perrin WF, Würsig B, Thewissen JGM, (ed) Encyclopedia of marine mammals (2nd edn). Academic Press, London, pp 638-642

Somera E, Florangel G (2013) The implementation of the solid waste management plan in the cities of Davao and Tagum, Philippines: a comparative study. 한 국행정 학 회 학 술발 표논 운 집 171-214.

Stacey PJ, Arnold PW (1999) Oracaella Brevirostris. Mamm Spec 616:1-8

STAP information document (2011) Marine debris as a global environmental problem. http://www.stapgef. org/sites/default/files/stap/wp-content/uploads/2013/05/Marine-Debris.pdf

Tavares DC, Moura JF, Acevedo-Trejos E, Merico A (2019) Traits shared by marine megafauna and their relationships with ecosystem functions and services. Front Mar Sci 6:262. https://doi.org/10.3389/ fmars.2019.00262

The Government of the Republic of Indonesia: Indonesia's plan of action on marine plastic debris 20172025. Executive summary (2017) Deputy for Human Resources, Science and Technology, and Maritime Culture Affairs.

Todd PA, Ong X, Chou LM (2010) Impacts of pollution on marine life in Southeast Asia. Biodivers Conserv 19:1063-1082. https://doi.org/10.1007/s10531-010-9778-0

Turner W (1904) The occurrence of the sperm whale or cachalot in the Shetland seas, with notes on the tympano-petrous bones of Physeter, Kogia, and other Odontoceti. Proc R Soc Edinb 24:423-436

Unger B, Rebolledo ELB, Deaville R, Gröne A, IJsseldijk LL, Leopold MF, Siebert U, Spitz J, Wohlsein P, Herr H (2016) Large amounts of marine debris found in sperm whales stranded along the North Sea coast in early 2016. Mar Pollut Bull 112:134-141. https://doi.org/10.1016/j.marpolbul.2016.08.027

United Kingdom Department for Environment Food and Rural Affairs (2015) Carrier bags: why there's a charge. https://www.gov.uk/government/publications/single-use-plastic-carrier-bags-why-were-intro ducing-the-charge/carrier-bags-why-theres-a-5p-charge

van der Hoop J, Corkeron P, Kenney J, Landry S, Morin D, Smith J, Moore MJ (2016) Drag from fishing gear entangling North Atlantic right whales. Mar Mamm Sci 32:619-642. https://doi.org/10.1111/ mms. 12292

van Emmerik T, van Klaveren J, Meijer LJJ, Krooshof JW, Palmos DAA, Tanchuling MA (2020) Manila River mouths act as temporary sinks for macroplastic pollution. Front Mar Sci 7:770. https://doi.org/ $10.3389 /$ fmars.2020.545812

West KL, Walker WA, Baird RW, Webster DW, Schorr GS (2018) Stomach contents and diel diving behavior of melon-headed whales (Peponocephala electra) in Hawaiian waters. Mar Mamm Sci 34:10821096. https://doi.org/10.1111/mms. 12507

Willoughby NG, Sangkoyo H, Lakaseru BO (1997) Beach litter: an increasing and changing problem for Indonesia. Mar Pollut Bull 34:469-478. https://doi.org/10.1016/S0025-326X(96)00141-5

Würsig B, Perrin WF, Thewissen JGM (eds) (2009) Encyclopedia of marine mammals. Academic Press, San Diego, CA

Xanthos D, Walker TR (2017) International policies to reduce plastic marine pollution from single-use plastics (plastic Bags and Microbeads): a review. Mar Pollut Bull 118:17-26. https://doi.org/10.1016/j. marpolbul.2017.02.048

Yamakita T, Sudo K, Jintsu-Uchifune Y, Yamamoto H, Shirayama Y (2017) Identification of important marine areas using ecologically or biologically significant areas (EBSAs) criteria in the east to Southeast Asia region and comparison with existing registered areas for the purpose of conservation. Mar Pol 81:273-284. https://doi.org/10.1016/j.marpol.2017.03.040

Publisher's Note Springer Nature remains neutral with regard to jurisdictional claims in published maps and institutional affiliations. 